\title{
Supporting Vocational Students' Development of Preventive Behaviour at Work: A Phenomenological Analysis of Teachers' Experiences
}

\author{
Alexandra Lecours*and Pierre-Yves Therriault \\ Département d'ergothérapie, Université du Québec à Trois-Rivières, 3351, boul. des Forges, \\ C.P. 500, Trois-Rivières, Québec, G9A 5H7, Canada
}

Received: 06.12.2016; Accepted: 07.03.2017; Published: 26.04.2017

\begin{abstract}
Statistics indicate that even if young workers complete vocational training, as a group they are at risk of sustaining injury. It appears that a lack of training in the area of injury prevention may explain some of this effect. Teachers are considered to be key actors in injury-prevention training and in the process of developing students' preventive behaviour at work, but little is known about the reality. The objective of this study was to understand how teachers experience their activities in support of students' development of injury-prevention behaviour at work. Semi-structured interviews were conducted with eleven teachers from four different vocational training programs. The content of the interviews was then examined using phenomenological analysis. Results show representations participants form of occupational health and safety, of injuryprevention behaviour and of their roles as teachers in relation to prevention. A closer look at these roles reveals the daily challenges teachers encounter. Among other things, there seems to be a lack of continuity in the training process, insufficient pedagogical resources and resistance on the students' part. Results offer an insight into teachers' experience with their part in the support of vocational students' development of injury-preventing behaviour. It appears they recognize having to play an active role in the development of injury-preventing behaviour at work among students, but have to face daily challenges affecting their teaching. Results of this study can serve as a starting point to make improvements to the injury-prevention training offered in vocational training centres.
\end{abstract}

\footnotetext{
${ }^{*}$ Corresponding author: Alexandra.Lecours@uqtr.ca
}

ISSN: 2197-8646

http://www.ijrvet.net 
Keywords: VET, Vocational Education and Training, Occupational Health and Safety, Prevention Training, Preventive Behaviour at Work, Teachers, Vocational Training, Young Workers

Acknowledgement: This work was supported by Fonds de Recherche du Québec Société et culture [Doctoral scholarship to first author], Acfas [Doctoral scholarship to first author], Institut de Recherche Robert-Sauvé en Santé et en Sécurité du Travail [Doctoral scholarship to first author] and Fondation Desjardins [Doctoral scholarship to first author]. 


\section{Introduction}

Statistics indicate that young workers are a group at risk of sustaining injury, even if they completed a vocational training (Girard, Doyon, Gilbert, Legris, \& Laliberté, 2006; Ledoux \& Laberge, 2006; Thivierge, 2002; Turner, Tucker, \& Kelloway, 2015). In fact, youth aged 15 to 24 are proportionally more often victims of an injury at work than their older colleagues (Breslin, Koehoorn, Smith, \& Manno, 2003; Ledoux \& Laberge, 2006; Salminen, 2004). In America, it is estimated that the frequency rate of occupational injuries among workers aged from 15 to 24 is $5.8 \%$, while it is of $3.7 \%$ among older workers (Hébert, Gervais, Duguay, Champoux, \& Massicotte, 2003). In Europe, the risk of work accidents among young workers is $25 \%$ to $40 \%$ higher in comparison with other age groups (Schneider, 2007). This higher risk to have a work injury for young workers could be related to the fact that these workers often have several organizational (eg. irregular hours, low pay) or physical (eg. repetitive work, heavy lifting) constraints in their jobs, compared to older age employees (Gervais, Massicotte, \& Champoux, 2006; Ledoux \& Laberge, 2006; Zierold \& Anderson, 2006). In addition to a lack of work experience (Breslin et al., 2003; Laberge, 2008; Passmore, Odnoda, Paine, \& Mohamed, 1991; Tétreault, 1994), the lack of training in terms of prevention is also reported as a factor influencing the frequency of work-related injuries or illnesses of youth (Laberge, Maceachen, \& Calvet, 2014; Ledoux et al., 2008; Moreau, Angora, \& Michel, 2013; Moscato et al., 2011). In this sense, training related to prevention provided by employers to young workers is often scarce (Ledoux, Laberge, \& Thuilier, 2015), low, or at least uneven between organizations (Smith \& Mustard, 2007). Moreover, the quality of such training is not reported in the literature (Breslin, Morassaei, Wood, \& Mustard, 2011; Zierold \& Anderson, 2006). It also appears that training related to prevention offered in vocational training centres seems insufficient and difficult to transfer when entering employment (Chatigny \& Desmarais, 2015). In fact, some authors reported that this training poorly prepares students to face the challenges of prevention they will experience in the labour market (Frigul \& Thébaud-Mony, 2010) or that learning made at school is only mobilized a little in work situations (Moreau et al., 2013). Training is an important antecedent in the development of preventive behaviour at work, which is considered a significant determinant of success in terms of prevention (Lecours \& Therriault, 2016b; Roy, Cadieux, Forter, \& Leclerc, 2008). It is then important to understand where the gaps are.

However, only few studies have attended to understand factors explaining weaknesses in prevention training offered in vocational training centres. It seems that although some government initiatives offer guidance tracks, no standard or policy is intended to standardize and structure the teachings of prevention in vocational programs, which leads to an inequality between different programs and vocational training centres in terms of available resources (human, financial, material and time) for training related to prevention (Chatigny, Nadon-Vézina, Riel, Couture, \& Hastey, 2012; Pisaniello et al., 2013). Scientific literature recognizes the central role that teachers play regarding the support to students' development of preventive behaviour at work (Chatigny et al., 2012; Hubert, Ulrich, Lindner, \& Murphy, 2003; Kaskutas et al., 2010; Moreau 
et al., 2013; Pisaniello et al., 2013), but it seems they face challenges in their daily activities (Chatigny et al., 2012; Moreau et al., 2013; Pisaniello et al., 2013; Schooley, 2012). Among others, it appears that the responsibility for the quality of training in prevention is not shared between the different actors of the education system, but mainly relegated to teachers (Chatigny \& Desmarais, 2015; Moreau et al., 2013; Passmore et al., 1991; Pisaniello et al., 2013). Defining course contents and teaching methods are based almost exclusively on their willingness and skills, which can create pressure on teachers as they often find themselves alone to bear the responsibility for teaching about prevention. Little information is currently available on the reality experienced by teachers of vocational training about their activities related to prevention and the few studies that have addressed this subject are mainly exploratory. As teachers are considered key actors in the development process of students' preventive behaviour at work (Andersson, Gunnarsson, \& Rosèn, 2015; Chatigny et al., 2012; Hubert et al., 2003; Kaskutas et al., 2010; Moreau et al., 2013; Hofman, Stalder, Tschan \& Hfeli, 2014), it is important to get an in-depth understanding of their reality in order to define the starting point to identify improvements required to make the training more effective. This article presents the results of a study that painted the portrait of the teachers' reality related to the support to students' development of preventive behaviour at work.

\section{Theoretical Background}

\subsection{Context of Vocational Training}

In the Canadian province of Quebec, training for a skilled or semi-skilled occupation is primarily offered in near of 200 vocational training centres. For the 2013-2014 academic year, 129348 students were registered in one of the programs offered (Gouvernement du Québec, 2015). These training programs are offered on a full-time basis and the duration of study is relatively short, ranging from 600 to 1,800 hours. These courses are offered to students from the age of 15 . However, the clientele in vocational training has a significant diversity in terms of student profiles. The clientele consists of minors coming directly from general high schools, but also of adults who have experienced periods of employment, education, or inactivity (Berbaoui, 2015; Chatigny \& Desmarais, 2015). Students aged 24 and under represent $55 \%$ of the population, while those over 30 years of age represent $30 \%$ of the clientele (Gouvernement du Québec, 2010). Very young people (under the age of 20 ) would represent only $17 \%$ of the vocational students (MELS \& MESRST, 2012). More than $60 \%$ of young students (24 years or younger) have a high school diploma upon entering vocational training, while only $40 \%$ of older students $(25$ years and older) have graduated. Vocational students consists of $56 \%$ of men (MELS \& MESRST, 2012). The organization of studies in vocational training is entirely oriented towards learning the trade. There is no general education. In addition, the curriculum is divided into multiple training modules for the development of specific skills. The duration of these modules varies between 15 and 135 hours of training. Many programs, but not all, include a module dedicated to education about prevention of work-related injuries or illnesses. However, this module is, for most study programs, generic and not 
specific to the occupation taught (Chatigny \& Desmarais, 2015). This module, when present, is usually given very early in the curriculum and has between 15 and 30 hours of instruction. Notions on the legislative framework for health and safety are addressed as well as risks to health or safety related to the occupation (Girard et al., 2006). Less frequently, working methods and skills to prevent these risks can be thaught (Girard et al., 2006).

A little more than 10000 teachers worked in Quebec's vocational training centres in 2009-2010. Many of them (76.1\%) have a precarious employment status and work at an hourly (or per lesson) rate or on a contract basis. They are mostly male, with an average age of 45.2 years (Gouvernement du Québec, 2012). Most of the teachers in vocational training centres are professionals in their field who decided to turn to teaching to transmit their knowledge or to live new challenges sometimes after a long career in their respective profession (Balleux, 2006). Although they are skilled at their occupation, few of them have received prior training to develop their teaching abilities (Moreau et al., 2013), and even less are trained to teach prevention. Only after they have been hired do they undertake university studies in vocational education if they wish to be granted tenure (Balleux, 2006; Gouvernement du Québec, 2001; Loignon, 2006). Since 2003, a bachelor's degree in vocational education is a requirement for tenure status. One distinguishing trait of the teaching context in vocational training centres is the expediency or urgency with which teaching resources are hired. Indeed, studies indicate that a large number of these teachers are hired a few days before their first lesson (Balleux, 2006; Chatigny et al., 2012; Gouvernement du Québec, 2012; Loignon, 2006). Hence, preparation time is short considering the content that must be covered.

\subsection{Definition of Preventive Behaviour at Work}

Recognized as a determinant of success in prevention of work-related injuries or illnesses (Roy et al., 2008), preventive behaviour is a predominant concept to develop among students to train young workers involved toward prevention. A recent study (Lecours \& Therriault, 2016b) highlighted the five attributes that define the concept of preventive behaviour at work, which are:

1) Compliance with safety rules and procedures;

2) Proactivity, participation, engagement and initiatives related to prevention;

3) Maintenance of the physical environment;

4) Concern for the social environment and;

5) Reflexivity and analytical skills of work situations.

Preventive behaviour at work is a complex concept that is formed of multiple attributes that interact together. Therefore, each of the attributes have to be developed among vocational students. Among others, the concept of preventive behaviour goes beyond 
compliance with the rules and procedures (attribute \#1) and participation in prevention activities (attributes \#2) (Griffin \& Neal, 2000; Hayes, Perandan, Smecko, \& Trask, 1998; Marchand, Simard, Carpentier-Roy, \& Ouellet, 1998). In fact, it asks the worker to think about prevention consistently, analyzing work situations before engaging into them and be on the lookout for risks. Preventive behaviour at work also requires worker to mobilize appropriate knowledge to engage in work activities without putting his health or safety at risk. Reflexivity and cognitive skills are thus required (attribute \#5) (Cossette, 2003; Garrigou, Peeters, Jackson, Sagory, \& Carballera, 2004; Ouellet \& Vézina, 2008). Also, communication with the social environment (attribute \#4) is an important caracteristic of preventive behaviour at work. In fact, multiple studies reported the importance of teamwork, mutual assistance and consultation with colleagues or supervisors as manifestations of preventive behaviour (Burke, Sarpy, Tesluk, \& Smith-Crowe, 2002; Cigularov, Chen, \& Rosecrance, 2010; Fugas, Silva, \& Meliá, 2011; Hayes et al., 1998; Hofmann, Morgeson, \& Gerras, 2003; Marchand et al., 1998). Finally, attention paid to physical environment, including cleanliness of work station and maintenance of equipment, is part of the preventive behaviour (attribute \#3) (Andriessen, 1978; Burke et al., 2002; Hayes et al., 1998; Lecours \& Therriault, 2016a; Marchand et al., 1998).

As preventive behaviour at work expresses observable and measurable actions that students can take to protect their own health and safety and that of their colleagues, it is then important for teachers to support and reinforce the development of the five attributes in their daily activities.

Although literature allows to understand the importance of teachers in terms of preventive education for students, little is known about their lived reality. To improve the quality of prevention training during vocational studies regarding students' development of the five attributes of preventive behaviour at work, a question remains: What is the experience lived by the key actors that are the teachers with regard to the support of vocational students' development of preventive behaviour at work? This article attempts to fill this gap in the state of knowledge.

\section{Objective}

The objective of this study was to understand how teachers experience their activities in support to students' development of preventive behaviour at work.

\section{Method}

\subsection{Research Design}

In order to understand the processes involved in teaching activities in support to students' development of preventive behaviour at work, a phenomenological qualitative design was followed (Fortin, 2010; Giorgi, 2009; O'Reilly \& Cara, 2015). A phenomenological design allows to describe the experience to be studied, namely the support to students' development of preventive behaviour at work, from the point of view of the 
population involved, namely teachers. This design allows the use of the significance that give people to their experiences to interpret and understand a lived experience. In fact, phenomenological design is interested in thoughts, impressions, feelings, interpretations, understandings and representations of participants (Broomé, 2011). This design is particularly useful for subjects studied little (Fortin, 2010), as it is the case in this study. Also, phenomenological design allows to describe the structure of a phenomenon, so that it can be understood in a deeper, holistic and comprehensive manner (Broomé, 2011).

\subsection{Participants}

Participants were teachers in vocational training. To be included in the study, participants had to meet the following criteria:

1. to have at least two years of experience as a teacher in vocational training;

2. to speak and to understand French;

3. to be engaged in one of targeted vocational programs, which were cooking, secretarial, hairstyling, automated systems electromechanical (ASE), located in two vocational training centres in the province of Quebec, Canada.

Study programs were identified in collaboration with the research team, the school principals and the intervener in youth prevention of the Commission for health and safety in the Canadian province of Quebec based on their different realities (e.g. number of hours allocated to the teaching of prevention, available resources) in order to represent the diversity of the teachers' reality. This concern for the diversification of participants is desired in the phenomenological design to collect divergent discourses and enrich the description of the phenomenon (Lincoln \& Guba, 1985; O'Reilly \& Cara, 2015). Teachers responsible of the module on prevention as well as teachers who have never specifically taught this training module were recruited in order to obtain a variety of experiences. No participant who was contacted declined to participate.

\subsection{Data Collection}

Individual, semi-structured interviews with open questions (e.g. How prevention is taught in your study program? or How do you define preventive behaviour at work?) were conducted with the participants. The aim was to collect information on their daily reality which pertains to the support to students' development of preventive behaviour. The interview framework has been validated with a pre-test method; its content and clarity were verified with two teachers from two vocational training centres, and modified and tested anew with another teacher before being used to gather information for this project. Interviews were recorded with digital audio, and the same framework was used for every participant. The preset order of questions was not methodic and could vary depending on the participants to allow for individual ways of structuring thoughts. The meetings lasted 45 to 90 minutes, were conducted in French and took place at the 
vocational training centres where participants work. After the ninth interview, responses started to become repetitive and little new information was founded, indicating saturation of content (Corbin \& Strauss, 2008). Due to the specificity of the subject, this was not unexpected. For this reason, after all participants who were initially contacted to participate in the study have completed the interviews, recruitment ended.

\subsection{Analysis}

A phenomenological analysis as described by Giorgi was used to analyze the data (Giorgi, 1997, 2009). The primary goal of phenomenological analysis is to derive meaning units from the raw data in order to capture the experience of participants, namely teachers, related to a phenomenon, namely the support to vocational students' development of preventive behaviour at work. After all interviews have been transcribed into verbatim, the corpus of data was analysed through the five-step process of the phenomenological analysis proposed by Giorgi (2009). First, a reading of the entire set of data was done in order to get a sense of the whole. Second, multiple other readings allowed to identify meaning units and to assign them a code. Open coding was favoured because of the inductive approach used. Units represented passages of discourse based on their meaning and relevance to the objective of exploring teachers' experience toward the support to students' development of preventive behaviour at work. The QSR NVivo 10 software was used to support the analysis. The third step was the transformation of meaning units into expressions that were revealing of the experience of participants. The fourth step allowed to synthetise a general structure of the comprehension of the phenomenon based on participants' experiences. Finally, the fifth step was used to refine the structure in order to clarify and interpret data related to participants' experience of the phenomenon. Several round trips between the raw interview data and the general structure allowed to fine-tune the analysis process. In order to improve validity of the analysis process, a second researcher verified the meaning units identified, the codes assigned and the strucure generated. Inter-rater agreement has been verified periodically through out the analysis process. After three rounds of coding, an inter-rater agreement has been found on more than $90 \%$ of the meaning units identified and codes assigned. Also, when both researchers agreed that the strucure generated allowed for a comprehension of the phenomenon according to participants' experience, a validation of the final results have been conducted with participants themselves. That final step ensured the representativness of the results obtained (Mukamurera, Lacourse, \& Couturier, 2006).

\subsection{Ethics}

The participants freely and voluntarily agreed to take part in the study, and no incentive was offered. This project was approved by the Université du Québec à Trois-Rivières' Comité d'éthique de la recherche avec des êtres humains [Ethics Committee for Research Involving Human Subjects] (CER-14-208-07.02). 


\section{RESULTS}

This section details characteristics of the study participants and categories that emerged from the analysis process. It is possible to delineate three categories of representation teachers have of 1) occupational health and safety (OHS), of 2) preventive behaviour and of 3 ) their roles as teachers. From these roles, three types of challenges teachers face on a daily basis were founded, which concern a) the teaching continuum, b) the available resources and c) the students' resistance to prevention education. Figure 1 illustrates the results obtained.

\subsection{Participants}

Eleven teachers from four study programs in two different vocational training centres participated in the study and completed the interview. Table 1 lists their main characteristics.

Table 1: Descriptive characteristics of participants

\begin{tabular}{ccccc}
\hline Participants & Age & Gender* & $\begin{array}{c}\text { Study } \\
\text { programs }\end{array}$ & $\begin{array}{c}\text { Number of } \\
\text { years of } \\
\text { teaching } \\
\text { experience }\end{array}$ \\
\hline 1 & 61 & F & ASE & 18 \\
\hline 2 & 37 & F & cooking & 10 \\
\hline 3 & 53 & M & cooking & 20 \\
\hline 4 & 47 & M & cooking & 20 \\
\hline 5 & 55 & M & hairstyling & 25 \\
\hline 6 & 58 & M & hairstyling & 13 \\
\hline 7 & 49 & F & hairstyling & 15 \\
\hline 8 & 33 & F & hairstyling & 13 \\
\hline 9 & 34 & F & hairstyling & 12 \\
\hline 10 & 69 & F & secretarial & 19 \\
\hline 11 & 58 & F & secretarial & 21 \\
\hline
\end{tabular}

${ }^{*} \mathrm{~F}=$ female, $\mathrm{M}=$ male

\subsection{Representations}

Analyses enabled to identify three types of representation that participants form, which are: I) representations of OHS; II) representations of preventive behaviour; III) representations of the teacher's role in relation with prevention. Table 2 shows the principal 
representations discussed by participants according to their study programs.

Table 2: Representations reported by participants of the different study programs

\begin{tabular}{|c|c|c|c|c|}
\hline & ASE & Cooking & Hairstyling & Secretarial \\
\hline \multicolumn{5}{|c|}{ I. Representations of OHS } \\
\hline OSH includes clients' safety & & & $\mathrm{x}$ & \\
\hline OSH includes hygiene and sanitation & & $\mathrm{x}$ & $\mathrm{x}$ & \\
\hline OSH is a collective responsibility & & $\mathrm{x}$ & & \\
\hline $\mathrm{OSH}$ is an individual responsibility & & & $\mathrm{x}$ & $\mathrm{x}$ \\
\hline \multicolumn{5}{|c|}{ II. Representations of preventive behaviour } \\
\hline $\begin{array}{l}\text { Preventive behaviour is the application } \\
\text { of prescribed rules and procedures }\end{array}$ & $\mathrm{x}$ & & & \\
\hline $\begin{array}{l}\text { Preventive behaviour is to adopt appro- } \\
\text { priate habits and work postures }\end{array}$ & $\mathrm{x}$ & $\mathrm{x}$ & $\mathrm{x}$ & $\mathrm{x}$ \\
\hline $\begin{array}{l}\text { Preventive behaviour is to properly } \\
\text { adapt the workplace and to have an ap- } \\
\text { propriate use of work equipment }\end{array}$ & $\mathrm{x}$ & $\mathrm{x}$ & $\mathrm{x}$ & $\mathrm{x}$ \\
\hline $\begin{array}{l}\text { Preventive behaviour is to know how to } \\
\text { analyze the tasks to identify the hazards } \\
\text { and risks }\end{array}$ & $\mathrm{x}$ & $\mathrm{x}$ & & $\mathrm{x}$ \\
\hline \multicolumn{5}{|c|}{ III. Representations of the teacher's role in relation with prevention } \\
\hline Avoid classroom injury & & & & $\mathrm{x}$ \\
\hline Be a model, set an example & & $\mathrm{x}$ & $\mathrm{x}$ & \\
\hline $\begin{array}{l}\text { Educate to the adoption of safe be- } \\
\text { haviour and to the importance of pre- } \\
\text { vention }\end{array}$ & $\mathrm{x}$ & $\mathrm{x}$ & $\mathrm{x}$ & $\mathrm{x}$ \\
\hline Ensure a safe environment & & & & $\mathrm{x}$ \\
\hline $\begin{array}{l}\text { Teach good working methods and assist } \\
\text { students in their application }\end{array}$ & $\mathrm{x}$ & $\mathrm{x}$ & $\mathrm{x}$ & $\mathrm{x}$ \\
\hline Teach to identify hazards & $\mathrm{x}$ & & & \\
\hline $\begin{array}{l}\text { Remind rules and correct individual be- } \\
\text { haviours }\end{array}$ & & $\mathrm{x}$ & $\mathrm{x}$ & $\mathrm{x}$ \\
\hline
\end{tabular}

\section{I) Representations of $\mathrm{OHS}$}

First of all, there is a semantic shift in the definition of OHS, with OHS getting confused with concerns for client safety, as evidenced in the following excerpts from the transcript: "It involves the health and safety of students, but also of clients. .... For example, we explain how to style hair without burning the client," and "For the practical exam, they 
[the students] have to style a client's hair. So we watch how they handle a hairdryer and curling iron, which can be harmful because it can burn the client." I

A semantic shift was also detected in the representations of OHS with participants in the cooking program, who mix OHS with hygiene and sanitation. One participant mentioned, "We also get into the hygiene and sanitation aspect, with the floors and all. We kind of throw that all in together."

Results also showed that the representation of the responsibility of OSH is different across study programs. Participants in the cooking program were the only ones who discussed OHS as being a collective rather than an individual responsibility. One participant explained the importance of teamwork in safe work practices:

You have to be mindful of other people. There can be dangers, not necessarily just for a given student, but also for the other people around him. While working, students walk around with knives, and there's a way of doing things, a proper procedure. Maybe the worker won't hurt himself, but other people around him [could get hurt]... You have to follow procedures. For example, there's a way to place pots on a hot plate, and it's important as much for the person working as it is for the others around him.

This representation of OHS as a collective responsibility was not evoked by participants in other programs, who mostly feel that OHS is an individual responsibility to comply with the rules. For example, a secretarial program participant said, speaking of her interactions with a student who was not properly seated on his chair: "As long as you're going to hold you like this, you're gonna have trouble." Another participant of this study program added, always referring to a discussion with a student who did not adopt a suitable working posture: "If you ever want to pick up with back pain, continue to sit like that because you will go straight there."

\section{II) Representations of preventive behaviour}

Participants in three programs (cooking, hairstyling and secretarial) defined preventive behaviour as the proper adjustment of the work station and work equipment as well as the adoption of appropriate work habits and safe postures. The appropriate use of work equipment is a representation shared by several participants. A participant of the cooking program illustrated: "It can be dangerous to use work equipment in a way they [the students] don't know. I tell them always to ask when they don't know how to work with an equipment. Don't improvise." A participant of the hairstyling program illustrated, in reference to examples of appropriate work habits in his work: "For me, gloves are very important. It is inconceivable to work with bleach without set gloves." Also, for participants in ASE, cooking and secretarial, preventive behaviour also involves knowing how to analyze situations, to discern the risks and thus be able to correct them. The following participant's thoughts clearly illustrate this representation:

\footnotetext{
${ }^{1}$ Sentences in quotes correspond to excerpts of transcripts of interviews with teachers who participated in the study. These transcripts were translated from French into English for this publication.
} 
Ultimately, the goal is to have a little warning bell that goes off in every situation. That is to say, they [the students] have to be able to say, 'Wait a minute, this situation is dangerous,' or, 'This is not right.' It has to be second nature. You look at a machine with its safety guard missing, and you have to notice it right away. You need to be able to spot the dangers.

III) Representations of the teacher's role in relation with prevention

Participants in all four study programs consider that when it comes to support students' development of preventive behaviour at work, one of their primary roles is to teach students good working habits and the importance of prevention in work activities. One participant spoke of being a "sensitizing agent" when it comes to prevention and wanting students to become "multiplying agents" for their peers.

According to participants in the cooking and hairstyling programs, they fill the role of being a model and exemplar for students in terms of prevention as well as the role of conveying proper work methods and assisting students in their application. The latter role is shared by teachers in all programs.

One role omnipresent among the participants in three programs, namely, cooking, hairstyling and secretarial programs, is that of providing frequent reminders of prevention rules and correcting behaviour that can result in injury. In this regard, one participant explained,

Whenever I see something that is not right, I have to say something right away and not wait. I can't let it slide even if I have already told the student three times. There are some [students] who need to be told six times before the message is understood.

Participants in only one program (secretarial) alluded to the role of offering students a safe working environment and the teacher's responsibility of preventing injuries from taking place in class.

\subsection{Challenges}

Analyses enabled to define and group challenges participants encounter in their roles related to students' development of preventive behaviour at work into three categories concerning: a) the prevention teaching continuum in the training program, b) the available resources and c) the students' resistance to prevention education. Table 3 shows the challenges identified by the participants.

Table 3: Challenges related to teacher's roles reported by participants of the different study programs 


\begin{tabular}{|c|c|c|c|c|}
\hline & ASE & Cooking & Hairstyling & Secretarial \\
\hline \multicolumn{5}{|c|}{ a. Challenges due to the prevention teaching continuum } \\
\hline $\begin{array}{l}\text { Inequality in prevention education ac- } \\
\text { cording to courses and teachers }\end{array}$ & & & $\mathrm{x}$ & \\
\hline Lack of knowledge about prevention & & & $\mathrm{x}$ & \\
\hline Lack of time for prevention education & & & & $\mathrm{x}$ \\
\hline $\begin{array}{l}\text { Little monitoring of prevention in in- } \\
\text { ternships }\end{array}$ & & $\mathrm{x}$ & $\mathrm{x}$ & $\mathrm{x}$ \\
\hline $\begin{array}{l}\text { Preventive behaviour is not an official } \\
\text { topic in the curriculum }\end{array}$ & & & & $\mathrm{x}$ \\
\hline \multicolumn{5}{|c|}{ b. Challenges due to the resources available } \\
\hline Lack of educational material & & $\mathrm{x}$ & $\mathrm{x}$ & $\mathrm{x}$ \\
\hline $\begin{array}{l}\text { Lack of financial means to purchase } \\
\text { equipment }\end{array}$ & & & & $\mathrm{x}$ \\
\hline $\begin{array}{l}\text { Lack of support from OSH Committee } \\
\text { of the institution }\end{array}$ & & $\mathrm{x}$ & & \\
\hline $\begin{array}{l}\text { Lack of training received related to the } \\
\text { prevention education }\end{array}$ & & $\mathrm{x}$ & $\mathrm{x}$ & $\mathrm{x}$ \\
\hline \multicolumn{5}{|c|}{ c. Challenges due to students' resistance to prevention education } \\
\hline Addictions of students & $\mathrm{x}$ & $\mathrm{x}$ & & \\
\hline High number of students per group & & & $\mathrm{x}$ & \\
\hline $\begin{array}{l}\text { Preventive behaviour is the first to } \\
\text { be neglected under stress compared to } \\
\text { technical skills }\end{array}$ & $\mathrm{x}$ & $\mathrm{x}$ & $\mathrm{x}$ & \\
\hline $\begin{array}{l}\text { Students are hard to raise awareness of } \\
\text { the importance of prevention }\end{array}$ & $\mathrm{x}$ & $\mathrm{x}$ & $\mathrm{x}$ & $\mathrm{x}$ \\
\hline $\begin{array}{l}\text { The experiences in the profession - } \\
\text { related workplaces negatively affect stu- } \\
\text { dent attitudes regarding prevention }\end{array}$ & & $\mathrm{x}$ & & \\
\hline
\end{tabular}

a) Challenges due to the prevention teaching continuum

One of the first challenges touched upon is the place given to prevention in the program. The matter of fact is that the topic is not officially part of the secretarial program according to government guidelines, so the integration of prevention concepts is entirely of the vocational training centre's initiative. That being said, participants said that without a proper time slot, there is just too little time to cover the topic. They decided to fit some prevention elements into an early module, but it is the only time students receive any formal training on the subject. One participant explained the challenge this lack of time poses: "Our way of managing it was to really integrate it. We did not have to, it takes up a lot of time, and time is the real problem here." 
It is a completely different reality for the teacher in ASE, where instruction on prevention teaching is overseen by a sectorial organization devoted to prevention and safety in the construction industry. In this context, the participant stated that a specific training is required for everyone who teaches the 30-hour course on general health and safety on job sites. This participant therefore has a teaching manual and various tools. Furthermore, every module of the curriculum begins with a lesson on applicable prevention measures. This participant did not talk about any challenges pertaining to the prevention teaching continuum.

In hairstyling, participants spoke of discrepancies with other classes and colleagues' teachings. The following participant elaborated on the challenges caused by these discrepancies:

Maybe I stress it more because I teach it [the module on prevention]. As soon as I see something wrong in the workshop, I correct the student. They [the other teachers] do it too, but less 'by the book,' perhaps. I'm even annoying when it comes to prevention .... I don't know if my colleagues dwell on it as much. We need to have everyone putting the same things into practice. If I teach something but they [the students] don't have any examples, or the other teachers don't do it, students will think they have to do certain things in front of Mr. So-and-so but not in other classes.

These discrepancies in teaching could stem from a challenge another participant in the hairstyling program pointed out, namely, a lack of knowledge related to prevention: "I don't really know what competency in OHS entails because I have never taught it."

The last issue with the teaching continuity, which was raised by participants in three of the four programs, is the minimal concern for prevention in practicum settings. This makes it hard to ensure continuity and coherence from an educational standpoint. In the secretarial program, for instance, the participant responsible for internships has this to say:

I oversee internships and visit all of the businesses. I would say that it's seriously not a top priority. I even find it absurd, because I see students at work stations that are completely ill-adapted and inadequate. They don't even have anything to prop up a sheet of paper. There is a huge deficiency among businesses. It's pretty flagrant.

A participant in hairstyling makes a similar observation: "I once did the practicum visits, and I didn't get the feeling that prevention play much of a role in the workplace reality."

\section{b) Challenges due to the available resources}

One of the most frequently cited challenges is participants' lack of training in teaching prevention. All participants indicated having received no training on the subject during their university studies in vocational education (they all possess a vocational teaching certificate, the mandatory diploma before 2003), and only one spoke of receiving continuing training to teach prevention. One participant in the hairstyling program said lack of training can impede teaching by making it difficult to discuss the topic in any real 
detail:

There is no doubt that I would like to know what to tell students who always want to know more. For example, 'What can happen when my wrist is like this (in full flexion)?' I don't know if it causes tendinitis or carpal tunnel, so I answer, 'It's just not good.' I wish I could tell them what can really happen.

The same participant talked about needing more training:

If there were experts professionally qualified in OHS to pass on just a bit of those skills, I think it would be good. Or, on our end, we could take regular refresher courses. It would be great to have someone who could help us brush up on the subject.

In the cooking program, another participant said insufficient prevention training directly impacts one's teaching:

When it comes to posture, I don't have much information to offer. Of course, we talk about posture, about standing correctly, being upright at your work station and so on. We adapt the work station to the student's height, but sometimes we have some students who are $1.49 \mathrm{~m}$ and others who are $1.89 \mathrm{~m}$, and we don't really know what to do for posture. Should we get a small bench to stand on or stack up boards on the table? We adapt as best we can, but we don't have a lot of information on the matter.

According to a participant in the secretarial program, the lack of financial means poses a challenge to teaching of prevention, because it is hard to adjust work stations without the necessary materials.

Another obstacle to teaching of prevention is the want of pedagogical materials. In both cooking and secretarial programs, participants have no training manual to help teach prevention. The content of their lessons comes mostly from a slide presentation created by a government organization that oversees prevention and fact sheets on how the program's cooking equipment works. Although the hairstyling program does have a manual, it does not meet all of their needs, as one person explained:

Sure, the module shows us all the OHS procedures for the workplace, but it's not very elaborated. It's very basic, and not necessarily geared toward hairstyling. Most of it has to do with work postures. It's really very basic.

Lastly, the participants in the hairstyling program reported having little support from their centre's OHS committee. "Yes, we have an OHS committee here at the school. Unfortunately, it doesn't have much to do with us. The committee is more concerned with machines. Because we deal with cosmetic products, there is nothing dangerous in our program." This foremost task of ensuring that equipment meets standards was 
described by nearly all participants as being the lone role their OHS committee plays, thereby demonstrating that they know little about the resources the committee can offer them.

The analysis of the transcript of the teacher in ASE revealed that unlike the other participants, this person does not attribute any challenges to a scarcity of resources. The participant spoke of receiving training and having access to teaching tools, while also relating the active role played by the OHS committee in the vocational training centre and all its study programs.

c) Challenges due to students' resistance to prevention education

Participants all agreed that making their students aware of the significance of prevention is an ongoing struggle. Students' young age and lack of life experience are a common explanation for this difficulty, as the following participant explained:

The younger students have no life experience outside having worked at [fast food restaurant chain]; it is hard to get to them. I like to draw a parallel with all the ad campaigns about safe driving. We repeat it ad nauseam, yet there are about 40 deaths [among young drivers] every year. They seem unreachable. It's as if bad things only happen to other people. It's very hard to get through to them and make them understand.

Teachers in the secretarial program also blamed the challenge of raising awareness among students on the fact that knowledge of prevention does not factor into the certification of studies. This participant put it as follows:

I think the greatest obstacle is a lack of interest. They [the students] don't see the importance, and it's not part of the program. Modules that are part of the program and needed to get the vocational diploma are all that matter to students. Anything beyond that often gets neglected.

Another participant in this program agreed, saying, "Sometimes, we get the impression they [the students] have the information and hit the 'eject' button because it will not be asked on the exam. I don't get the sense that it matters much to them. I really don't."

In cooking, three participants considered that current or past work experience has a negative influence on the importance students give to prevention, and teachers must constantly fight the less than edifying view of prevention in the restaurant industry, as reflected by this participant: "It is difficult because many of our students already work in the restaurant industry, and it [prevention] is really neglected. We have a lot of work to do to convince them that it is important."

Others stated that one of the challenges they observe with students is the prioritization of competencies, since they note that in times of stress, preventive behaviour is neglected compared to technical skills. One excerpt from a participant in the hairstyling program illustrates this assessment: 
It is certainly not easy for them [the students], since they are in the learning process and have a lot to think about. First, they have to be comfortable with the client. Then, they have to use the proper techniques. So having the right posture is secondary.

Another participant expanded on this point with an example from the cooking program:

We also tell them [the students], from the very beginning, 'Don't leave your knives in the sink.' But it still happens. They'll be in the dining room, feeling stressed. They want to save time. So they leave a knife in the sink. And then maybe another student happens by and puts his hand in the sink and cuts himself. When they are stressed, they sometimes take shortcuts when it comes to OHS.

Finally, the large number of students in each group and students who attend class while under the influence of drugs constitute daily challenges for teachers. Figure 1 illustrates the representations and challenges described by the participants.

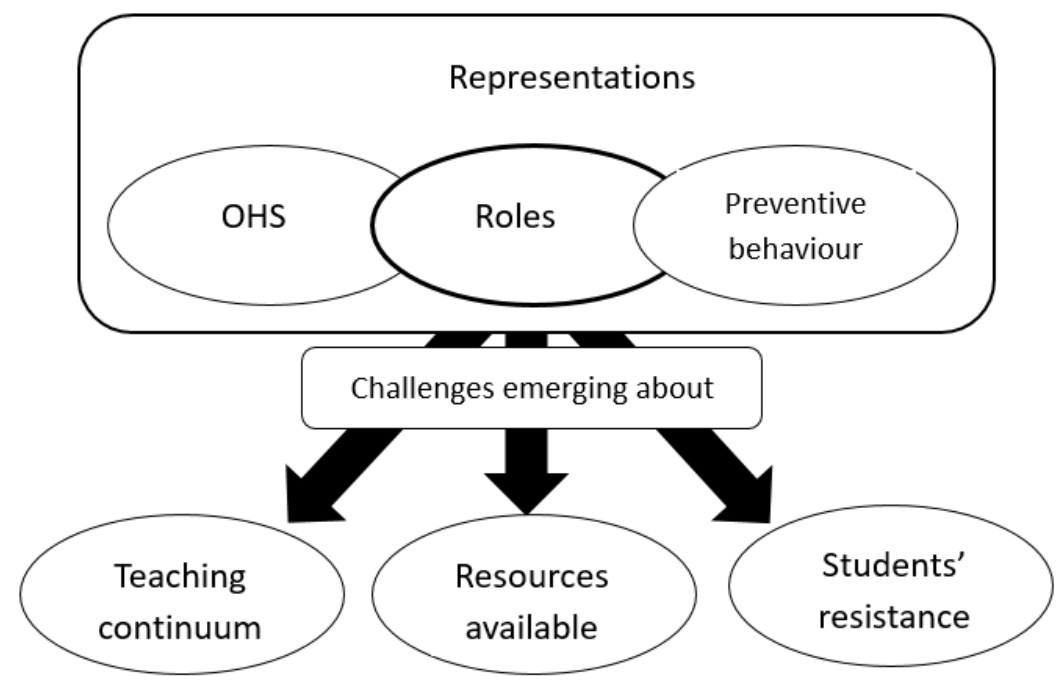

Figure 1: Mapping of representations and challenges expressed by participants

\section{Discussion}

The study presented in this article has provided an insight into teachers' experience of activities in support to students' development of preventive behaviour at work. Analyses 
allowed to identify three types of representation, from which emerged three different categories of challenges faced by teachers.

\subsection{Representations}

It is interesting to note that the discourse of participants allows to understand that teachers are trying to develop most of the attributes of the concept of preventive behaviour at work among their students. In fact, the different representations participants form of OHS, preventive behaviour or of their roles as teachers refer to attributes of the concept of preventive behaviour. First, most of the participants consider the importance of the application of rules and procedures, as well as the adoption of appropriate habits, which may be related to the attribute of compliance with safety rules and procedures (attribute \# 1) of the concept of preventive behaviour at work, as described earlier (Lecours \& Therriault, 2016b). Participants explored this attribute in their representation of preventive behaviour, but also in their roles as a teacher who has to support students' development of preventive behaviour at work.

Moreover, most participants described the importance taken to the adaptation of the work station and the appropriate use of work equipment, which may be related to the attribute of the maintenance of the physical environment (attribute \# 3).

The attribute \# 4 referring to the concern for social environment is also highlighted by participants of the cooking program in their representation of the OSH as a collective responsibility. This attribute was thus not present in the discourse of participants from other study programs. It is true that among the four study programs taking part in this research, the cooking program is the one that prepares students for an occupation that requires the most collaboration. In the other programs, colleagues tend to work more parallel to each other without a production line or dependence on each other's activities.

A last attribute of the concept of preventive behaviour may be extracted from the discourse of participants; it is the attribute \#5 related to the reflexivity and analytical skills of work situations. This characteristic is considered as a representation of the preventive behaviour at work by several participants, but is considered as a role by only one. Interestingly, it appears that teachers recognize the importance of reflexivity and analytical skills of work situations to develop preventive behaviour, but only one assigned a role to teachers in supporting students deal with this attribute. As it has been shown that strict compliance with safety regulations and cautious behaviour has little impact on the occurrence of work-related injuries and illnesses (Simard \& Marchand, 1997), it is important to work on developing vocational students' ability to express all of the attributes of the concept, including the capacity to assess work situations in order to mobilize the appropriate knowledge (Dejours, 1987; Simard \& Marchand, 1997). Training in this sense should be offered to teachers.

Attribute \# 2 on the proactivity, participation, engagement and initiatives related to safety at work was not mentioned in the discourse of participants. Teachers did not mention that this feature could be part of their representation of prevention. This could be related to the stage of future workers. Indeed, students learning a trade are in a listening posture, assimilation of information and adjustment. They are probably 
not yet advanced enough in learning their occupation to propose initiatives, changes or to demand. However, results of a recent study suggested that self-advocacy regarding safety at work, including leadership skills, would gain to be promoted in school settings in order to enable young workers to be active regarding prevention in the workplace (Chin et al., 2010).

\subsection{Challenges}

Participants encounter several major challenges in their roles of support to students' development of preventive behaviour at work; foremost among them are the absence of training and scarcity of pedagogical tools. They all say the same thing, namely, that they received no instruction on teaching prevention during the university studies in vocational education they were required to complete. This is consistent with a recent Australian study, in which the teachers surveyed deem their lack of prevention training hinders their ability to teach the subject (Pisaniello et al., 2013). This deficiency in teachers' training might explain the different interpretations certain participants have of OHS, especially those who mix notions of OHS with hygiene and sanitation or OHS with customer safety. This semantic shift had also been reported in an anterior study (Chatigny et al., 2012). One of the resources teachers can turn to for support in their role related to prevention is their institution's OHS committee. However, teachers seem to believe that the committee's sole purpose is to see to upgrading equipment. This is in line with a government priority in terms of prevention in vocational training centres which stipulates that the material, equipment and environment must meet recognized prevention standards (Gouvernement du Québec, 2005). This same conclusion was reached in an earlier study, which stated that improving material and equipment was a priority until 2013, and programs preparing students for "high risk" occupations (e.g. construction) were at the top of the list (Chatigny \& Riel, 2014). It seems that work needs to be done with institutions' OHS committees so they can support teachers in other priorities of action, such as integrating the teaching of prevention into the entire vocational training process. As teachers are key actors in prevention training of students (European agency for safety and health at work, 2006), it is particularly important to implement the means to support them.

Results also display a marked diversity in the different study programs' realities in terms of the importance given to prevention in their teachings and pedagogical resources available. In the secretarial program, ministry specifications do not contain any requirements as to the learning of prevention and, therefore, does not set aside any time for teaching and evaluating this topic. The participating vocational training centre's syllabus includes certain prevention notions out of a personal initiative, but teachers perceive this initiative is taking time away from other topics required for the diploma. This time constraint relative to prevention education is consistent with results of other studies (Pisaniello et al., 2013). The situation in ASE is completely different. Education to prevention is a foremost concern in the program, due in equal part to the wishes of the government, vocational training centre and teachers. The fact that the prevention teaching module is overseen by a sectorial organization means teachers have 
access to ongoing training and pedagogical tools on which to base their lessons. Teachers themselves note the disparities in support given to different programs. Teachers in the hairstyling and secretarial programs say they feel that since their work presents a lower risk of injuries than the more gruelling occupations, they receive less support in their efforts to support students' development of preventive behaviour at work. This discrepancy in time and resources allotted for the teaching of prevention among the different study programs is reported in other Canadian (Chatigny et al., 2012) and international (Pisaniello et al., 2013) texts as well. This could be explained, in part, by the fact that the current teachings on prevention in educational settings depend greatly on the will of teachers (Andersson et al., 2015; Chatigny \& Desmarais, 2015; Laberge et al., 2012; Moreau et al., 2013; Passmore et al., 1991; Pisaniello et al., 2013; Schulte, Stephenson, \& Okun, 2005). These often bear sole responsibility for developing preventive behaviour of students.

With regard to students' development of preventive behaviour at work, practicums offer little follow-up on what is being taught in vocational training centres, as it has been found in previous studies (Chatigny et al., 2012; Moreau et al., 2013). This presents another considerable challenge for teachers, who must diligently strive to show the importance of preventive behaviour that is downplayed in practicum environments. Considering that workers build their professional identity by assimilating every work-related experience (Gohier et al., 2001) - positive and negative - the dichotomy in the message communicated to students as to the significance of prevention can have negative repercussions on how they internalize the value of prevention. Greater synergy between the school and practicum settings would be beneficial. To this end, the government would have to issue clear guidelines.

Finally, all of the teachers refer to challenges arising from the difficulty of making students grasp the importance of prevention, which is consistent with other recently published texts (Pisaniello et al., 2013). They perceive students as being "unreachable" or as displaying "wishful thinking" that workplace injuries and occupational diseases cannot happen to them. As attitudes and beliefs about prevention have been found to be significantly related to the explanation of behaviour among youth (Blair, Seo, Torabi, \& Kaldahl, 2004; Crowe, 1995), this is an important concern to address. Many teachers attribute attitude of students toward prevention to a lack of life experience. Some add that students who have experienced or witnessed a situation in which a worker has suffered an accident or work-related illness better understand the importance of prevention teachings and become more receptive. This fits in with literature suggesting that people are more likely to engage in preventive actions and develop preventive behaviour at work if they have experienced emotions that prompt a greater level of awareness (Cossette, 2013). In the same vein, the concept analysis of preventive behaviour revealed that the motivation, as part of the human affectivity, is an important antecedent of the behaviour (Lecours \& Therriault, 2016b). Considering that many vocational students have only just entered adulthood and have little work experience, it is recommended that prevention training given during vocational studies be used to illicit these emotions that lead to a greater awareness to favour the development of preventive behaviour at work. 


\subsection{Limitations of this Study}

The principal limitation of this study is the small sample. Only eleven teachers and two vocational training centres took part in the study. Even if saturation of content appeared to be reached and that programs were rigorously selected to reflect the different realities, it would be beneficial to lead similar research on a larger scale. In fact, this study reflects the reality of vocational teachers in one province of Canada. Results may have been different in other Canadian areas or in other countries. Moreover, the uneven number of participants from each study program may have influenced the conclusions drawn from the findings. Finally, all participants had completed the university certificate in vocational education, which was the mandatory diploma before 2003. Maybe results would have been different if the study had been conducted with participants who completed the bachelor's degree. However, given the innovative aspect of this study on a little explored subject and the rigorous phenomenological analysis process, the scope of the results remains interesting.

\section{Conclusion}

This study has given an insight of how teachers experience their activities related to support to students' development of preventive behaviour at work. Results enabled to report representations they form of OHS, of preventive behaviour and of their roles as teachers in relation with prevention. These roles then allowed to identify the challenges they face daily. Among others, we found a disparity in the importance given to teaching prevention from one program to another, a lack of continuity throughout the training curriculum, a lack of training and pedagogical tools available as well as a students' resistance to the teachings offered. Since teachers are key actors for vocational students' development of preventive behaviour, it is important to suggest solutions for the challenges presented herein. The results of this study can serve as a starting point to make improvements to the prevention training offered in vocational training centres. 


\section{References}

Andersson, I.-M., Gunnarsson, K., Rosèn, G. (2015). Role of headmasters, heachers, and supervisors in knowledge transfer about occupational health and safety to pupils in vocational education. Saf health work, 6(4), 317-323. http://dx.doi.org/10.1016/j.s haw.2015.07.012

Andriessen, J. (1978). Safe behavior and safety motivation. Journal of occupational health accidents, 1, 363-376.

Balleux, A. (2006). Les étudiants en formation à l'enseignement professionnel au Québec : portrait d'un groupe particulier d'étudiants universitaires. Canadian journal of higher education, 36(1), 29-48.

Berbaoui, A. (2015). Les jeunes de 16-24 ans inscrits en formation professionnelle et les obstacles à leur participation à la formation. Available at ProQuest Dissertations \& Theses Full Text.

Blair, E. H., Seo, D.-C., Torabi, M. R., \& Kaldahl, M. A. (2004). Safety beliefs and safe behavior among midwestern college students. J Safety Res, 35(2), 131-140. http://dx.doi.org/http://dx.doi.org/10.1016/j.jsr.2003.11.003

Breslin, C., Koehoorn, M., Smith, P., \& Manno, M. (2003). Age related differences in work injuries and permanent impairment: a comparison of workers' compensation claims among adolescents, young adults, and adults. J Occup Env Med, 60(9), E10.

Breslin, F. C., Morassaei, S., Wood, M., \& Mustard, C. A. (2011). Assessing occupational health and safety of young workers who use youth employment centers. Am J Ind Med, 54(4), 325. http://dx.doi.org/10.1002/ajim.20937

Broomé, R. E. (2011). Descriptive phenomenological psychological method: an example of a methodology section from doctoral dissertation. Available at ProQuest Dissertations \& Theses Full Text.

Burke, M., Sarpy, S. A., Tesluk, P., \& Smith-Crowe, K. (2002). General safety performance: A test of a grounded theoretical model. Pers Psychol, 55(2), 429-457.

Chatigny, Nadon-Vézina, L., Riel, J., Couture, V., \& Hastey, P. (2012). Analyse ergonomique de la santé et de la sécurité en centre de formation professionnelle (46). Montréal: IRSST.

Chatigny, C., \& Desmarais, L. (2015). L'intégration de la santé et de la sécurité dans la formation des élèves et des enseignants de la formation professionnelle (129). Montréal: CSST-MEESR.

Chatigny, C., \& Riel, J. (2014). La santé et la sécurité des élèves en centre de formation professionnelle: approche, représentations, et genre. Pistes, 16(4), On line. http://dx.doi.org/10.4000/pistes.4402

Chin, P., DeLuca, C., Poth, C., Chadwick, I., Hutchinson, N., \& Munby, H. (2010). Enabling youth to advocate for workplace safety. Safety Sci, 48(5), 570-579. http://dx.d oi.org/http://dx.doi.org/10.1016/j.ssci.2010.01.009

Cigularov, K. P., Chen, P. Y., \& Rosecrance, J. (2010). The effects of error management climate and safety communication on safety: A multi-level study. Accid Anal Prev, 42(5), 1498-1506. http://dx.doi.org/10.1016/j.aap.2010.01.003

Corbin, J. M., \& Strauss, A. L. (2008). Basics of qualitative research (3rd ed.). Thousand 
Oaks, Calif.: Sage Publications, Inc.

Cossette, R. (2003). Prévenir: savoir, savoir-faire, savoir-être, faire savoir. Prévention au travail, 16(2), 8-10.

Cossette, R. (2013). Le comportement sécuritaire, un modèle qui pourrait rallier deux écoles de pensée. Travail et Santé, 29(1), 6-9.

Crowe, J. W. (1995). Safety values and safe practices among college students. Journal of Safety Research, 26(3), 187-195. http://dx.doi.org/10.1016/0022-4375(95) 00010-N

Dejours, C. (1987). Plaisir et souffrance dans le travail. Orsay.

European agency for safety and health at work. (2006). Intégration de la sécurité et de la santé au travail dans l'éducation: bonnes pratiques à l'école et dans l'enseignement professionnel. Luxembourg.

Fortin, M.-F. (2010). Fondements et étapes du processus de recherche. Montréal: Chenelière éducation.

Frigul, N., \& Thébaud-Mony, A. (2010). Où mène le Bac pro? enseignement professionnel et santé au traval des jeunes. Paris: L'Harmattan.

Fugas, C. S., Silva, S. A., \& Melia, J. L. (2011). Another look at safety climate and safety behavior: Deepening the cognitive and social mediator mechanisms. Accid Anal Prev, 45, 468-477. http://dx.doi.org/10.1016/j.aap.2011.08.013

Garrigou, A., Peeters, S., Jackson, M., Sagory, P., \& Carballera, G. (2004). Apports de l'ergonomie à la prévention des risques professionnels. In P. Falzon (Ed.), Ergonomie (1st ed., 457-514). Paris: Presses universitaires de France.

Gervais, M., Massicotte, P., \& Champoux, D. (2006). Conditions de travail, de santé et de sécurité des travailleurs du Québec (140). Montréal: IRSST.

Giorgi, A. (1997). De la méthode phénoménologique utilisée comme mode de recherche qualitative en sciences humaines : théories, pratique et évaluation. In J. Poupart (Ed.), La recherche qualitative : enjeux épistémologiques et méthodo-logiques (341364). Montréal: Gatan Morin.

Giorgi, A. (2009). The descriptive phenomenological method in psychology: A modified Husserlian approach. Pittsburg, PA: Duquesne University.

Girard, S. A., Doyon, P., Gilbert, L., Legris, M., \& Laliberté, D. (2006). Santé et sécurité du travail et formation professionnelle : Prochaine cible d'intérêt. Pistes, 8(2), On line.

Gohier, C., Anadon, M., Bouchard, Y., Charbonneau, B., Chevrier, J., Chené, A., \& Roy, G.-R. (2001). La construction identitaire de l'enseignant sur le plan professionnel: un processus dynamique et interactif. Revue Des Sciences De L'éducation, 27(1), $3-32$.

Gouvernement du Québec. (2001). La formation à l'enseignement professionnel: Les orientations, les compétences professionnelles (192). Québec.

Gouvernement du Québec. (2005). Formation professionnelle et technique. Mieux intégrer les compétences en santé et sécurité au travail: une mission prioritaire! (14). Québec.

Gouvernement du Québec. (2010). La formation professionnelle et technique au Québec: un aperçu. Québec.

Gouvernement du Québec. (2012). état de la situation de la formation à l'enseignement 
professionnel au Québec. Québec: Table MELS-Universités.

Gouvernement du Québec. (2015). Nombre d'inscriptions par programme de formation professionnelle, selon le type de diplôme recherché, le secteur de formation, le sexe, le type de fréquentation scolaire, la langue d'enseignement, la strate d'âge et le statut d'élève débutant, année scolaire 2013-2014. Page consultée à http://www.education.gouv.qc.ca/

Griffin, M. A., \& Neal, A. (2000). Perceptions of safety at work: A framework for linking safety climate to safety performance, knowledge, and motivation. J Occup Health Psychol, 5(3), 347-358.

Hayes, B. E., Perandan, J., Smecko, T., \& Trask, J. (1998). Measuring perceptions of workplace safety: development and validation of the work safety scale. J Safety Res, 29(3), 145-161.

Hébert, F., Gervais, M., Duguay, P., Champoux, D., \& Massicotte, P. (2003). Les jeunes: contraintes du travail et risques. Communication présentée 2ième congrès national de l'Association canadienne de recherche en santé au travail ACRST/CARWH, Montréal.

Hofmann, C., Stalder, B. E., Tschan, F. \& Hfeli, K. (2014). Support from teachers and trainers in Vocational education and training: The pathways to career aspirations and further career development. International Journal for Research in Vocational Education and Training (IJRVET), 1(1), 1-20. doi: 10.13152/IJRVET.1.1.5

Hofmann, D. A., Morgeson, F. P., \& Gerras, S. J. (2003). Climate as a moderator of the relationship between leader-member exchange and content specific citizenship: safety climate as an exemplar. J Appl Psychol, 88(1), 170-178. http://dx.doi.org/1 0.1037/0021-9010.88.1.170

Hubert, D., Ulrich, D., Lindner, J., \& Murphy, T. (2003). An examination of Texas agriculture teacher safety attitudes based on a personal belief scale score from common safety and health practices. Journal od Agricultural Systems, Technology, and Management, 17, 1-13.

Kaskutas, V., Dale, A. M., Lipscomb, H., Gaal, J., Fuchs, M., \& Evanoff, B. (2010). Changes in fall prevention training for apprentice carpenters based on a comprehensive needs assessment. J Safety Res, 41(3), 221-227. http://dx.doi.org/ 10.1016/j.js r.2010.01.006

Laberge, M. (2008). Les TMS et les jeunes: enjeux et perspectives de recherche pour une prévention durable.

Laberge, M., Maceachen, E., \& Calvet, B. (2014). Why are occupational health and safety training approaches not effective? Understanding young worker learning processes using an ergonomic lens. Safety Sci, 68, 250-257. http://dx.doi.or g/10.1016/ j.ssci.2014.04.012

Laberge, M., Vézina, N., Calvet, B., Lévesque, S., Vézina-Nadon, L., Déom, E., Cloutier, E. (2012). Supervision of Apprentices in Semiskilled Trades: Program Stipulations and Workplace Realities. Relations industrielles, 67(2), 199-221.

Lecours, A., \& Therriault, P. (2016a). French transcultural validation of the Compliance with Safety Behavior Scale. Work, 55(4), 805-815. http://dx.doi.org/10. 3233/WOR-162445 
Lecours, A., \& Therriault, P. (2016b). Preventive behavior at work - A concept analysis. Scand J Occup Ther, On line(Epub ahead of print), 1-10. http://dx.doi.or $\mathrm{g} / 10.1080 / 11038128.2016 .1242649$

Ledoux, É., Laberge, L., \& Thuilier, C. (2015). Portrait de l'accueil et de la formation à l'embauche des étudiants occupant un emploi pendant l'année scolaire (31). Montréal: IRSST.

Ledoux, É., Laberge, L., Thuilier, C., Prud'homme, P., Veillette, S., Gaudreault, M., \& Perron, M. (2008). étudier et travailler en région à 18 ans quels sont les risques de SST : une étude exploratoire. Montréal: IRSST.

Ledoux, É., \& Laberge, M. (2006). Bilan et perspectives de recherche sur la SST des jeunes travailleurs. Montréal: IRSST.

Lincoln, Y. S., \& Guba, E. G. (Eds.). (1985). Naturalistic inquiry. Newbury Park, CA: Sage Publications.

Loignon, K. (2006). Etude compréhensive sur le phénomène d'attrition hâtive en enseignement professionnel au Québec: Certains facteurs à considérer. Available at ProQuest Dissertations \& Theses Full Text.

Marchand, A., Simard, M., Carpentier-Roy, M.-C., \& Ouellet, F. (1998). From a unidimensional to a bidimensional concept and measurement of workers' safety behavior. Scand J Work Environ Health, 24(4), 293-299. http://dx.doi.org/10.5 271/sjweh.323

MELS \& MESRST. (2012). Indicateurs de l'éducation. Québec: Repéré à http://www.ed ucation.gouv.qc.ca/fileadmin/site_web/documents/PSG/statistiques_info_decisionne lle/Indicateurs_educ_2012_webP.pdf

Moreau, J. P., Angora, C., \& Michel, X. (2013). Gestion des enjeux de santé au travail dans l'enseignement professionnel. Nantes: Académie de Nantes.

Moscato, G., Pala, G., Boillat, M. A., Folletti, I., Gerth Van Wijk, R., Olgiatides Gouttes, D., Tarlo, S. M. (2011). EAACI position paper: prevention of workrelated respiratory allergies among preapprentices or apprentices and young workers. Allergy, 66(9), 1164-1173. http://dx.doi.org/10.1111/j.1398-9995.2011.02615.x

Mukamurera, J., Lacourse, F., \& Couturier, Y. (2006). Des avancées en analyse qualitative: pour une transparence et une systématisation des pratiques. Recherches qualitatives, 26(1), 110-138.

O’Reilly, L., \& Cara, C. (2015). La phénoménologie de Husserl. Dans M. Corbière \& N. Larivière (éds.), Méthodes qualitatives, quantitatives et mixtes (29-50). Québec, Canada: Presses de l'Université du Quénec.

Ouellet, S., \& Vézina, N. (2008). Savoirs professionnels et prévention des TMS: réflexions conceptuelles et méthodologiques menant à leur identification et à la genèse de leur construction. Pistes, 10(2), On line.

Passmore, D. L., Odnoda, M., Paine, R., \& Mohamed, D. A. (1991). Epidemiology of work injuries among former participants in vocational education. Communication presented at $14^{\text {th }}$ annual congress of the Northeast educational research association, Ellenville.

Pisaniello, D. L., Stewart, S. K., Jahan, N., Pisaniello, S. L., Winefield, H., \& Braunack-Mayer, A. (2013). The role of high schools in introductory occupational safety education - Teacher perspectives on effectiveness. Safety Sci, 55(2013), 53-61. 
http://dx.doi.org/http://dx.doi.org/10.1016/j.ssci.2012.12.011

Roy, M., Cadieux, J., Forter, L., \& Leclerc, L. (2008). Validation d'un outil d'autodiagnostic et d'un modèle de progression de la mesure en santé et sécurité du travail (28). Montréal: IRSST.

Salminen, S. (2004). Have young workers more injuries than older ones? An international literature review. J Safety Res, 35(5), 513-521. http://dx.doi.org/10.10 16/j.jsr.2004.08.005

Schneider, E. (2007). Young workerfacts and figures. Page consultée à https://osha.europa.eu/en/tools-and-publications/publications/reports/7606507

Schooley. (2012). High school teacher drives home the safety message. Worksafe magazine, January/February, 18-21.

Schulte, P. A., Stephenson, C. M., \& Okun, A. H. (2005). Integrating occupational safety and health information into vocational and technical education and other workforce preparation programs. Am J Public Health, 95(3), 404-411. http://dx.doi.org/10.21 05/AJPH.2004.047241

Simard, M., \& Marchand, A. (1997). La participation des travailleurs à la prevention des accidents du travail: formes, efficacité et déterminants (40). Montréal: IRSST.

Smith, P. M., \& Mustard, C. A. (2007). How many employees receive safety training during their first year of a new job? Inj Prev, 13(1), 37. http://dx.doi.org/10.1 136/ip.2006.013839

Tétreault, P. (1994). Les jeunes au travail et la problématique de la santé et de la sécurité du travail. Montréal.

Thivierge, C. (2002). Jeunes et prévention. De l'école au boulot. Prévention au travail, $15(4), 7-14$.

Turner, N., Tucker, S., \& Kelloway, E. K. (2015). Prevalence and demographic differences in microaccidents and safety behaviors among young workers in Canada. J Safety Res, 53(0), 39-43. http://dx.doi.org/http://dx.doi.org/10.1016/j.js r.2015.0 3.004

Zierold, K. M., \& Anderson, H. A. (2006). Severe injury and the need for improved safety training among working teens. Am J Health Behav, 30(5), 525. 


\section{Bibliographical Note}

Alexandra Lecours is an occupational therapist, a $\mathrm{PhD}$ candidate and a lecturer at Université du Québec à Trois-Rivières, Canada. Her doctoral thesis is about the development of preventive behaviour at work among students learning a trade.

Dr Pierre-Yves Therriault is a regular professor in occupational therapy at Université du Québec à Trois-Rivières, Canada. His is also the director of the "Laboratoire de recherche en ergologie". His current research are on the field of health at work. 